DEPÓSITO LEGAL ZU2020000153

Esta publicación científica en formato digital

es continuidad de la revista impresa

ISSN 0041-8811

E-ISSN 2665-0428

Revista

de la

Universidad

del Tunlia

Fundada en 1947

por el Dr. Jesús Emrique Lossada

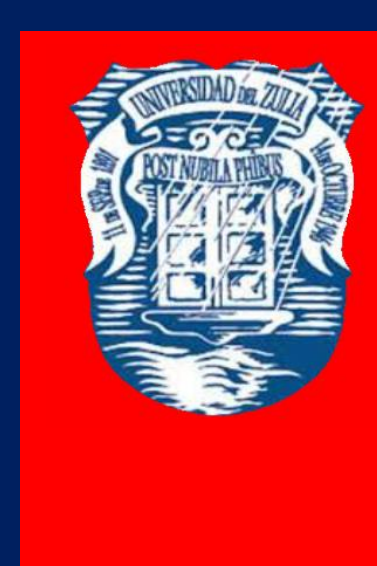

Ciencias

Sociales

y Arte

Aกัต 11 No 31

Septiembre - Diciembre 2021

Tercera ípoca

Maracailbo-Venezuela 
REVISTA DE LA UNIVERSIDAD DEL ZULIA. 3e época. Año $11 N^{\circ}$ 31, 2020

Esmaeil Dargahi \& Arash Tahriri /// Representing a Model for Implementing International...141-159

DOI: http://dx.doi.org/10.46925//rdluz.31.11

\title{
Representing a Model for Implementing International Financial Reporting Standards in Iran
}

\author{
Esmaeil Dargahi * \\ Arash Tahriri **
}

\begin{abstract}
International Financial Reporting Standards (IFRS) are global, identical, high-quality and comprehensive standards for financial reporting that have been developed by the International Accounting Standards Board (IASB). The objective of the current study is to represent a model for the implementation of the International Financial Reporting Standards in Iran. This study is an applied research and can be considered a qualitative research. A survey is applied in this regard. The statistical population of the study consisted of members of the accounting faculty of universities, financial managers, and boards of directors of companies listed on the Tehran Stock Exchange and the Iran Fara Stock Exchange. In this study, the snowball sampling method was used. In this research, 15 experts were initially selected as the initial research sample, then 25 people were added to the initial research volume, and 40 people were selected as the final sample. Based on the results of the interpretive structural model, cultural factors are the prerequisites for all factors that affect the adoption and dissemination of International Financial Reporting Standards (IFRS), and the cost and benefits of applying IFRS have the same greater impact on the adoption and dissemination of these standards.
\end{abstract}

KEYWORDS: International Financial Reporting Standards, Iran, Tehran Stock Exchange.

\footnotetext{
* PhD candidate Tehran University.

** Accounting Professor, Tehran University.
}

Recibido: 13/05/2020

Aceptado: 08/07/2020 
REVISTA DE LA UNIVERSIDAD DEL ZULIA. 3época. Año $11 \mathrm{~N}^{\circ}$ 31, 2020

Esmaeil Dargahi \& Arash Tahriri /// Representing a Model for Implementing International...141-159

DOI: http://dx.doi.org/10.46925//rdluz.31.11

\section{Representación de un modelo para implementar las Normas Internacionales de Información Financiera en Irán}

RESUMEN

Las Normas Internacionales de Información Financiera (NIIF) son normas globales, idénticas, de alta calidad y comprensibles para la información financiera que han sido desarrolladas por el Consejo de Normas Internacionales de Contabilidad (IASB). El objetivo del estudio actual es representar un modelo para la implementación de las Normas Internacionales de Información Financiera en Irán. Este estudio es una investigación aplicada y puede considerarse una investigación cualitativa. Se aplica al respecto una encuesta. La población estadística del estudio consistió en miembros de la facultad de contabilidad de las universidades, gerentes financieros y juntas directivas de empresas que cotizan en la Bolsa de Valores de Teherán y la Bolsa de Irán Fara. En este estudio, se utilizó el método de muestreo de bola de nieve. En esta investigación, en un principio se seleccionaron 15 expertos como muestra inicial de la investigación y luego se agregaron 25 personas al volumen inicial de la investigación, y se seleccionaron 40 personas como muestra final. Con base en los resultados del modelo estructural interpretativo, los factores culturales son los requisitos previos para todos los factores que afectan la adopción y difusión de las Normas Internacionales de Información Financiera (NIIF), y el costo y los beneficios de aplicar las NIIF tienen el mayor impacto en la adopción y difusión de estos estándares.

PALABRAS CLAVE: Normas Internacionales de Información Financiera, Irán, Bolsa de Valores de Teherán.

Introduction

The homogenization of accounting standards has been defined as the process of increasing the comparability of accounting practices by limiting the areas of difference and differentiation (Nobes, 2010). The incentive to homogenization is driven by the need and demand of investors looking for the best investment opportunities with limited economic resources. As the financial information of listed companies in stock market is used by both domestic and foreign investors, international investors force regulatory and codifying bodies to homogenize accounting standards globally. It is assumed that with the introduction and application of a single set of accounting standards, the significant differences between the 
REVISTA DE LA UNIVERSIDAD DEL ZULIA. 3a época. Año 11 N 31, 2020 Esmaeil Dargahi \& Arash Tahriri /// Representing a Model for Implementing International...141-159

DOI: http://dx.doi.org/10.46925//rdluz.31.11

national accounting systems of different countries will gradually decrease, thereby the comparability and comprehensibility of corporate financial statements will increase worldwide. To this end, governments are adopting and implementing international standards, including international financial reporting standards, in order to maintain domestic investors and attract foreign investors.

\section{Statement of the problem}

Nowadays, due to the intensification of capital flows as a result of globalization, timely and comparable access to financial information and reports has gained a special place. This is very important for investors because investors are always willing to invest in a place where they can make the most return, and this does not occur unless they have access to transparent, timely and comparable financial information. In this regard, the existence of well-defined standards for reporting financial statements at the international level will not only reduce the costs of evaluating financial statements, but will also eliminate the uncertainty caused by the lack of transparency, which will also play an important role in the allocation of better financial resources at the international level (Nazari et al, 2013). International Financial Reporting Standards (IFRSs) exactly play this role and have practically become the common language of financial reporting (Guevara Sanabria et al, 2020). Despite all the benefits of adopting International Financial Reporting Standards (IFRSs), there are also obstacles to homogenization, including that accounting is affected by contingent factors. So, it seems difficult and perhaps impossible to provide an ideal global accounting system for all countries.

\section{Theoretical bases of the investigation}

\subsection{History and Foundation of International Financial Reporting Standards (IFRS)}

The Foundation of the International Financial Reporting Standards, as the reference for compiling International Financial Reporting Standards, was first established in June 1973 in London under the name of the International Accounting Standards Committee, and then, on April $1^{\text {st }}, 2001$, was renamed as the International Financial Reporting Board. The Board had 14 members, and since April 2001, it has been solely responsible for setting accounting standards 
REVISTA DE LA UNIVERSIDAD DEL ZULIA. 3a época. Año 11 N³1, 2020

under the Foundation of the International Financial Reporting Standards. The foundation is an independent, non-profit, private organization that works for the public interest and aims to create a single, high-quality, comprehensible, practical, and global set of international financial reporting standards through its standardized body, the International Accounting Board or the same International Accounting Standards Committee that was set up in 2001. International Financial Reporting Standards (IFRSs) are the global, high-quality, comprehensible standards for financial reporting that have been set up by the International Accounting Standards Board. The aim of these standards is to prepare financial statements of stock companies based on a global standard. The growth of international trade and the flows of capital and increasing economic integration over the past two decades have led to the desire to the homogenization of accounting standards across countries.

\subsection{The Impact of Applying International Financial Reporting Standards (IFRSs) on the Quality of Financial Reporting}

High quality information is the most important factor in the efficiency of capital markets. In the meantime, the accounting system and the accepted principles on which it relies have a vital role in preparing and presenting financial information to external users who use this information to make economic decisions (Ahmed et al., 2013). The results which have been so far obtained from empirical research on the application of International Financial Reporting Standards (IFRSs) in different countries have been variable (Brown, 2011). European Parliament and Council of Ministers' requirement of European companies to comply international financial reporting standards has increased studies on investigating voluntary accruals following the adoption of mandatory application of International Financial Reporting Standards (Byard et al., 2011).

\subsection{Research Background}

Hajiha et al. (2017) in a study entitled "Investigating Factors Affecting on Specifying Time for Training International Financial Reporting Standards (IFRS) " concluded that factors of attitudes toward IFRS, the number of faculty members, the experience of instructors and the 
REVISTA DE LA UNIVERSIDAD DEL ZULIA. 3a época. Año 11 N 31, 2020 Esmaeil Dargahi \& Arash Tahriri /// Representing a Model for Implementing International...141-159

DOI: http://dx.doi.org/10.46925//rdluz.31.11

quality of educational resources are critical determinants of time allocation for training International Financial Reporting Standards (IFRSs).

Soleimani Amiri and Rasouli (2017), in a study entitled "The Approach of Accounting Society of Iran in Adopting International Financial Reporting Standards (IFRS)", found that homogenizing accounting standards is a worthwhile goal, and although there are some disagreements on how to apply IFRS (IFRS) ), the majority of professionals are in favor of adopting these standards and achieving the goal of homogenizing and adhering to global standards.

Aghasi (2015), in a study aimed at examining the barriers to complete adoption of International Financial Reporting Standards (IFRS) by the Tax Administration, found that the lack of economic development infrastructure was at the most important barrier to the adoption.

Hejazi et al. (2013) in a study found that based on the opinion of academics, auditors and accountants, the adoption of International Financial Reporting Standards (IFRSs) has an economic impact on the Iranian environment. In addition, there was no significant difference between the respondents' opinions.

Maradona and Chand (2018), in a study titled "The Pathway of Transition to International Financial Reporting Standards (IFRS) in Developing Countries: Evidence from Indonesia", based on their empirical findings, have determined several issues and challenges in the gradual implementation of International Financial Reporting Standards (IFRS), and have identified potential models for determining the success of current IFRS convergence programs in other areas.

Lee et al. (2017) in a study found that substantial aspects of accounting quality have enhanced since the adoption of IFRSs. It has also been effective in predicting future earnings and cash flows.

Alzeban (2016) found in a study that the factors of instructors' attitude, accounting department size, training style, type of institution, training experience and educational content are effective in transferring the concepts of International Financial Reporting Standards (IFRS) to students. 
REVISTA DE LA UNIVERSIDAD DEL ZULIA. 3a época. Año 11 N 31, 2020

Hellmann \& Perera (2014) in a study entitled "The adoption of International Financial Reporting Standards in a non-colonized developing country: The case of Nepal" indicated that their decision to adopt International Financial Reporting Standards (IFRS) in Nepal was not due to the needs of local organizations but it has been imposed by donor organizations such as the Asian Development Bank, the IMF and the World Bank.

Zahri and Chouabi (2013), using a sample of 24 developing countries, found that economic growth, education level, and the legal system had a significant impact on the adoption of IFRS by developing countries. However, factors such as culture, the existence of the capital market and the political system do not have a significant effect on the adoption of these standards.

\section{Research Methodology}

The present study is considered an applied research, on the other hand, it is categorized as library and field research. Also, with regard to relying on in-depth interviews and presented questionnaires to the interviewees, it can be considered as a qualitative research. In another categorization, it is a survey type and an exploratory one. The statistical population of the study consisted of accounting faculty members of universities, financial managers and board of directors of companies listed in Tehran Stock Exchange and Iran Fara Bourse. In this study, snowball sampling method was used. In this study, at first 15 experts were selected as the sample of the research and then according to their discretion, 25 people were added to the initial volume of the research, and 40 people were selected as the final sample. As this study is a descriptive, applied research, for data collection, documentation methods, library survey, interviews and questionnaires were used. In this research, the data analysis method is the theme analysis technique. That is, through the thematic method, first the factors affecting the adoption of IFRS are identified, and then they are modeled and prioritized by structural-interpretive modeling. Also, for descriptive-inferential analysis of research variables and their relationships, SPSS and LISREL software will be used. Additionally, the Kolograph-Smirnov test was used to analyze the data obtained by the questionnaire. 
REVISTA DE LA UNIVERSIDAD DEL ZULIA. 3a época. Año 11 N 31, 2020

Esmaeil Dargahi \& Arash Tahriri /// Representing a Model for Implementing International...141-159

DOI: http://dx.doi.org/10.46925//rdluz.31.11

\subsection{Research purposes}

- Designing an Adoption and Dissemination Model for International Financial Reporting Standards (IFRS) in Iran;

- Identifying the effective and determinant factors of the adoption and dissemination of International Financial Reporting Standards (IFRSs) in Iran.

\subsection{Research Hypotheses}

The proposed model and framework is appropriate for identifying the factors affecting the adoption and dissemination of International Financial Reporting Standards (IFRSs).

\section{Research Findings}

Data analysis was performed in SPSS 19. Tests were performed at 0.05 level of error. Data analysis was performed in two sections of descriptive and inferential statistics. In the descriptive findings section, central and distribution indices such as mean, median, minimum and maximum and standard deviation were presented. In the inferential section, two-sample $t$ test was used.

Describing and evaluating the impact of factors affecting the application of International Financial Reporting Standards (IFRSs)

Describing and reviewing the homogenization of the application of International Financial Reporting Standards (IFRS) with national standards

It can be seen from the above table that the significance level associated with Chi-square (1.074) is equal to 0.584 ( $\mathrm{P}$-Value> 0.05). Therefore, it can be declared that there is no significant difference between the responsiveness of the two groups of experts regarding the implementation and homogenization of International Financial Reporting Standards (IFRS) within Iran. 
Table (1): The results of Chi-square test on the significant difference between the responses of experts from university- stock market

$\begin{array}{llcc}\text { Tests } & \text { values } & \begin{array}{c}\text { Degrees of } \\ \text { freedom }\end{array} & \begin{array}{c}\text { Chi-square test } \\ \text { Significance level (two-way) }\end{array} \\ \text { Chi-square (Pearson) } & 1.074^{\mathrm{a}} & 2 & .584 \\ \text { Likelihood-ratio test } & 1.082 & 2 & .582 \\ \text { linearity assumption } & .049 & 1 & .824 \\ \text { Total number } & 40 & & \end{array}$

Reviewing and describing the comprehensive application of IFRSs

Four ranges have been used to assess the comprehensiveness of IFRSs. All experts are in favor of replacing IFRS standards with national standards under different conditions.

Table (2): The results of Chi-square test on the significant difference between responses of experts from university-stock market

$\begin{array}{lccc}\text { Tests } & \text { values } & \begin{array}{c}\text { Degrees of } \\ \text { freedom }\end{array} & \begin{array}{c}\text { Chi-square test } \\ \text { Significance level (two-way) }\end{array} \\ \text { Chi-square (Pearson) } & 2.90 & 3 & 0.40 \\ \text { Likelihood-ratio test } & 3.69 & 3 & 0.2968 \\ \text { linearity assumption } & 1.10 & 1 & 0.294 \\ \text { Total number } & 40 & & \end{array}$

Investigating and describing the costs and benefits of applying IFRS 
Table (3): The results of Chi-square test on the significant difference between responses of experts from university-stock market

$\begin{array}{lccc}\text { Tests } & \text { values } & \begin{array}{c}\text { Degrees of } \\ \text { freedom }\end{array} & \begin{array}{c}\text { Chi-square test } \\ \text { Significance level (two-way) }\end{array} \\ \text { Chi-square (Pearson) } & 2.90 & 3 & 0.40 \\ \text { Likelihood-ratio test } & 3.69 & 3 & 0.2968 \\ \text { linearity assumption } & 1.10 & 1 & 0.294 \\ \text { Total number } & 40 & & \end{array}$

Describing and investigating the challenges of implementing International Financial Reporting Standards (IFRS) in Iran

Table 4: Comparing the Challenges of Implementing International Financial Reporting Standards (IFRS) in Iran in Two Groups

\begin{tabular}{l|cccccc} 
Challenge & $\begin{array}{c}t- \\
\text { statistic }\end{array}$ & $\begin{array}{c}\text { Degree of } \\
\text { freedom }\end{array}$ & Sig & $\begin{array}{c}\text { Mean } \\
\text { difference }\end{array}$ & $\begin{array}{c}\text { upper } \\
\text { limit }\end{array}$ & lower limit \\
\hline Staff training & -2.49 & 38 & 0.017 & -0.8 & -0.149 & -1.45 \\
$\begin{array}{l}\text { Use of experts } \\
\begin{array}{l}\text { Use of audit } \\
\text { firms }\end{array}\end{array}$ & $\begin{array}{l}3.39 \\
\text { tax laws }\end{array}$ & 38 & 0.002 & 0.95 & 1.51 & 0.381 \\
& -1.648 & 38 & 0.108 & -0.5 & 0.114 & -1.11
\end{tabular}

From the above table, the results of $\mathrm{t}$-student test revealed that the level of significance related to the comparison of staff training in the two groups (financial managers and professors) was equal to 0.017 (sig $<0.05$ ). Therefore, it can be said that there is a significant difference between the two groups regarding the challenge of staff training.

Describing and investigating the responsibility of training accountants for the implementation of International Financial Reporting Standards (IFRS) in Iran. 
REVISTA DE LA UNIVERSIDAD DEL ZULIA. 3ª época. Año 11 N 31, 2020 Esmaeil Dargahi \& Arash Tahriri /// Representing a Model for Implementing International...141-159

DOI: http://dx.doi.org/10.46925//rdluz.31.11

Table 5: Comparison of the amount of responsibility of training accountants for implementation of International Financial Reporting Standards (IFRSs) in Iran

\begin{tabular}{l|cccccc} 
Challenge & $\begin{array}{c}\mathrm{t} \text { - } \\
\text { statistic }\end{array}$ & $\begin{array}{c}\text { Degree of } \\
\text { freedom }\end{array}$ & Sig & $\begin{array}{c}\text { Mean } \\
\text { difference }\end{array}$ & upper limit & lower limit \\
\hline $\begin{array}{l}\text { audit firms } \\
\begin{array}{l}\text { Government and } \\
\text { regulatory agencies }\end{array}\end{array}$ & 7.29 & 38 & 0.000 & 1.6 & 2.04 & 1.15 \\
Auditors & -1.29 & 38 & 0.2 & -0.4 & 0.225 & -1.025 \\
Universities & 3.73 & 38 & 0.001 & 1.1 & 1.69 & 0.503 \\
& -6.02 & 38 & 0.000 & -1.6 & -1.06 & -2.13
\end{tabular}

From the table above, the results of the $t$-student test indicate that the level of significance for comparing the responsibility of training auditors by audit firms in the two groups (financial managers and professors) is equal to 0.000 (sig <0.05). Therefore, it can be said that there is a significant difference in the level of responsibility of auditors to train auditors in the two groups. Also, from the table above, the results of $\mathrm{t}$-student test show that the level of significance related to comparing the level of responsibility of the government accountants and supervisory bodies in the two groups (financial managers and professors) was equal to 0.20 (sig> 0.05). Therefore, there is no significant difference between the opinion of financial managers and academic professors regarding the level of responsibility by the government and supervisory bodies in training accountants.

According to the above table and the results of the $t$-student test, it was found that the level of significance related to the comparison of auditors' training responsibility by the auditors in the two groups (financial managers and professors) was 0.001 (sig «0.05). Therefore, it can be said that there is a significant difference between the two groups regarding the responsibility of training auditors. Again, based on the information in the table above and the results of the $t$ student test, it was found that the level of significance associated with comparing the responsibility of teaching accountants by universities in the two groups (financial managers and professors) was equal to 0.000 (sig $<0.05$ ). Thus, it can be said that there is a significant 
REVISTA DE LA UNIVERSIDAD DEL ZULIA. 3ª época. Año $11 \mathrm{~N}^{\circ}$ 31, 2020

DOI: http://dx.doi.org/10.46925//rdluz.31.11

difference between the opinions of the two groups regarding the responsibility of teaching accountants by universities.

Describing and investigating the advantages of applying International Financial Reporting Standards (IFRS) in Iran.

Table 6 and the results of the $t$-student test reveal that the level of significance related to the increase in comparability of the two groups (financial managers and teachers) was equal to 0.022 (sig $<0.05$ ). Therefore, it can be said that there is a significant difference in the comparability of IFRS from the point of view of the two groups.

Table 6: Comparing the Advantages of Applying International Financial Reporting Standards (IFRS) in Iran in Two Groups

\begin{tabular}{|c|c|c|c|c|c|c|}
\hline Challenge & $\begin{array}{l}\mathrm{t}- \\
\text { statistic }\end{array}$ & $\begin{array}{l}\text { Degree of } \\
\text { freedom }\end{array}$ & Sig & $\begin{array}{l}\text { Mean } \\
\text { difference }\end{array}$ & upper limit & lower limit \\
\hline $\begin{array}{l}\text { Increasing } \\
\text { comparability }\end{array}$ & 2.39 & 38 & 0/022 & 0.5 & $0 / 923$ & $0 / 768$ \\
\hline $\begin{array}{l}\text { Increasing } \\
\text { reliability }\end{array}$ & 1.43 & 38 & $0 / 159$ & $0 / 35$ & $0 / 843$ & $-0 / 143$ \\
\hline $\begin{array}{l}\text { Attracting foreign } \\
\text { investors }\end{array}$ & -0.224 & 38 & $0 / 824$ & $-0 / 5$ & $0 / 402$ & $-0 / 502$ \\
\hline Reducing the & & 38 & & & & \\
\hline likelihood of fraud & 2.35 & & $0 / 024$ & $0 / 5$ & 0/929 & $0 / 07$ \\
\hline
\end{tabular}

Again, based on the results of the above table and the $t$-student test, it is found that the level of significant related to increasing the reliability and attraction of foreign investors through application of International Financial Reporting Standards (IFRS) from the two groups' points of view (financial managers and professors), was respectively 0.159 and 0.824 , respectively (sig> 
REVISTA DE LA UNIVERSIDAD DEL ZULIA. 3a época. Año 11 N 31, 2020 Esmaeil Dargahi \& Arash Tahriri /// Representing a Model for Implementing International...141-159

DOI: http://dx.doi.org/10.46925//rdluz.31.11

0.05). Therefore, there is no significant difference between the viewpoints of financial managers and academic professors regarding the increase in the reliability and attraction of foreign investors through application of IFRSs. The level of increase in reliance and attraction of foreign investors caused by the application of International Financial Reporting Standards (IFRSs) is considered the same by the two groups.

The results also show that the level of significance associated with the reduction of the probability of fraud caused by the application of International Financial Reporting Standards (IFRS) from the two groups' points of view (financial managers and professors) was equal to 0.024 (sig <0.05). Therefore, it can be said that there is a significant difference between the two groups' points of view on reducing the probability of fraud caused by the application of International Financial Reporting Standards (IFRS).

Describing and investigating the impact of environmental factors on the adoption of International Financial Reporting Standards (IFRSs) in Iran

Table 7: Comparing the Impact of Environmental Factors on the Adoption of International Financial Reporting Standards (IFRSs) in Iran

\begin{tabular}{l|cccccc}
$\begin{array}{l}\text { Environmental } \\
\text { factors }\end{array}$ & $\begin{array}{c}\mathrm{t} \text { - } \\
\text { statistic }\end{array}$ & $\begin{array}{c}\text { Degree of } \\
\text { freedom }\end{array}$ & Sig & $\begin{array}{c}\text { Mean } \\
\text { difference }\end{array}$ & upper limit & lower limit \\
\hline public training & 0.001 & 38 & 0.999 & $0 / 000$ & $0 / 453$ & $-0 / 453$ \\
$\begin{array}{l}\text { Openness of } \\
\text { Economy Degree }\end{array}$ & 0.462 & 38 & $0 / 647$ & 1 & $0 / 538$ & $-0 / 338$ \\
Economic Growth & 1.40 & 38 & $0 / 168$ & $0 / 35$ & $0 / 853$ & $-0 / 153$ \\
Capital Market & 1.79 & 38 & $0 / 081$ & $0 / 5$ & $1 / 06$ & $-0 / 064$
\end{tabular}

The above table and the results of $t$-student test show that the significant levels associated with the impact of all environmental factors are greater than 5\% error (sig> 0.05). Therefore, there is no significant difference between the viewpoints of financial managers and university professors regarding the impact of environmental factors (public training, economic 
REVISTA DE LA UNIVERSIDAD DEL ZULIA. 3a época. Año ll N³1, 2020

DOI: http://dx.doi.org/10.46925//rdluz.31.11

openness, economic growth and capital market) on the adoption of International Financial Reporting Standards (IFRS) in Iran. Both groups consider the same level of impact for the environmental factors on the adoption of IFRSs.

Describing and investigating the impact of allocation of training time on the adoption of International Financial Reporting Standards (IFRSs).

It can be seen in table 8 that the level of significance associated with chi-square (1.034) is equal to 0.596 (P-value> 0.05). Therefore, there is no significant difference between the responses of the two groups of experts regarding the attitude towards the existence of International Financial Reporting Standards (IFRS) in the study plan.

Table 8 shows a significant difference between the responses of experts from university-stock market
Tests
values
Degrees of
Chi-square test
freedom
Significance level (two-way)

Chi-square (Pearson)

1.034

2

Likelihood-ratio test

1.04

2

0.596

linearity assumption

0.783

1

0.594

Total number

40

Training Materials: How is the quality and availability of training resources of IFRS assessed?

Table 9 significance between responses of experts from university- stock market

Tests

Chi-square (Pearson)

Likelihood-ratio test

linearity assumption

Total number values

1.012

1.026

0.983

40
Degree of

freedom

2

2

1
Chi-square test

Significance level (two-way) 
REVISTA DE LA UNIVERSIDAD DEL ZULIA. $3^{a}$ época. Año 11 N 31, 2020 Esmaeil Dargahi \& Arash Tahriri /// Representing a Model for Implementing International...141-159

DOI: http://dx.doi.org/10.46925//rdluz.31.11

It can be seen from the above table that the significance level associated with chi-square (1.012) is equal to 0.6 (P-Value> 0.05). Therefore, it can be declared that there is no significant difference between the responses of the two groups of experts regarding the access to materials and educational resources of IFRS in Iran. In other words, both expert groups (university-stock market) have the same views and theories.

Describing and investigating the amount of the impact of cultural factors on the barriers to implementation of International Financial Reporting Standards (IFRS) in Iran.

Table 10: Sample t-test results for comparing the mean of cultural factors with number 3

$$
\text { Test Value }=3
$$

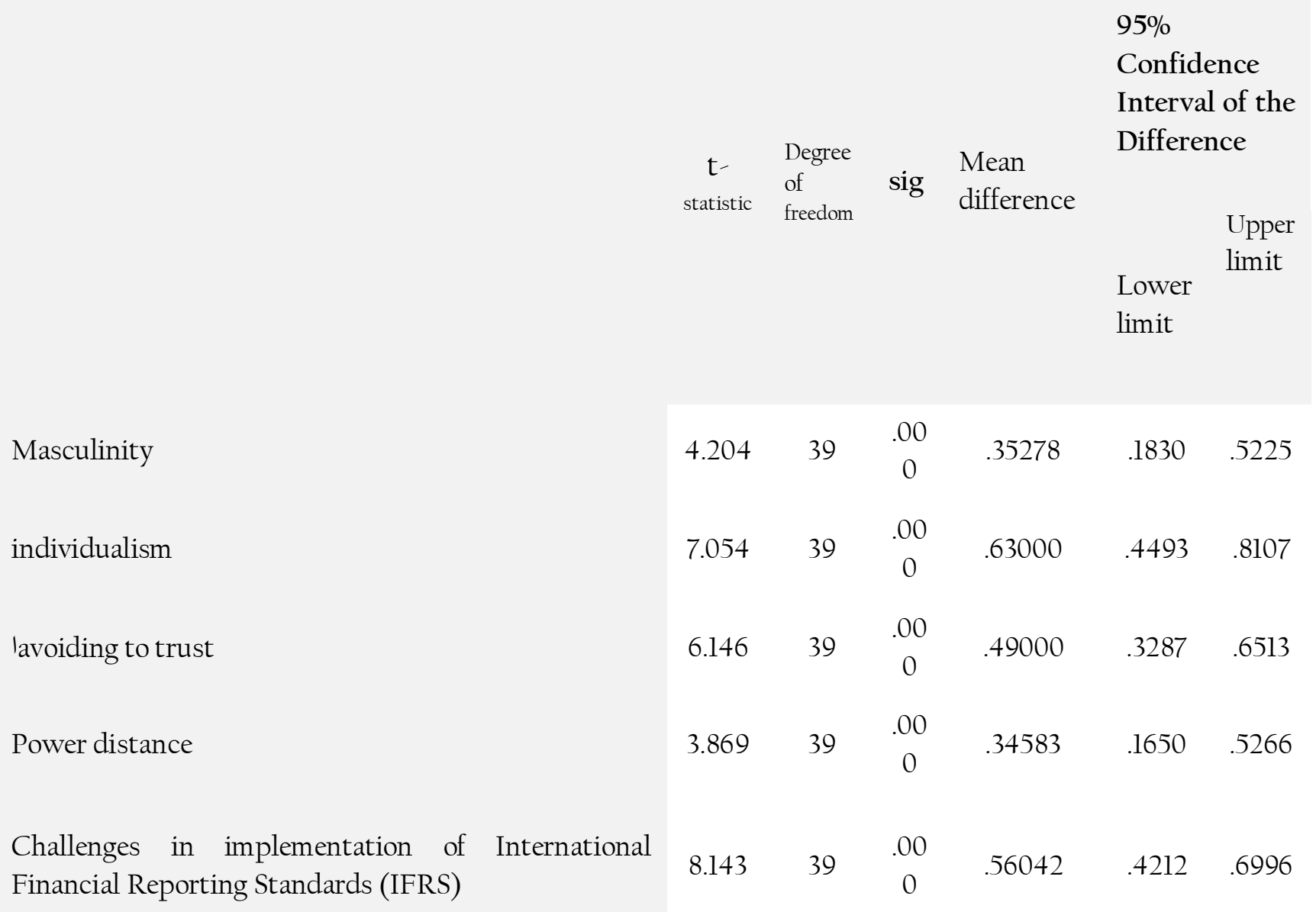


REVISTA DE LA UNIVERSIDAD DEL ZULIA. 3ª época. Año $11 \mathrm{~N}^{\circ}$ 31, 2020 Esmaeil Dargahi \& Arash Tahriri /// Representing a Model for Implementing International...141-159

DOI: http://dx.doi.org/10.46925//rdluz.31.11

The table above shows that all significant levels related to the factors and barriers to IFRS implementation are 0.000 (sig $<0.05$ ). The mean differences also show that cultural factors affecting the implementation of International Financial Reporting Standards (IFRS) and the implementation barriers of International Financial Reporting Standards (IFRS) are above the expected confidence level of (95\%).

Structural Interpretive Modeling of Factors Affecting the Adoption and Dissemination of International Financial Reporting Standards (IFRSs) in Iran

The following table shows the iterations and levels of each agent.

Table 1l: Classification of Factors Affecting the Adoption and Dissemination of International Financial Reporting Standards (IFRSs) in Iran

\begin{tabular}{|lllll|}
\hline factor & Input set & Output set & commonality & level \\
2 & $1-2-3-5-6-7-8-9$ & $-1-6-9$ & $-1-6-9$ & 6 \\
3 & $-2-4-5-7-8$ & $-1-2-3-4-7-9$ & $-2-4-7$ & 2 \\
4 & $2-3-4-5-6-7-8-9$ & $-1-3-4-6-7-9$ & $-3-4-6-7-9$ & 4 \\
5 & $-2-3-4-5-7$ & $-2-3-4-5-7$ & $-2-3-4-5-7$ & 7 \\
6 & $-4-5-7-9$ & $1-2-3-4-5-6-7-$ & $-4-5-7-9$ & 3 \\
7 & $-1-3-5-6-8-9$ & $-1-3-6-7-9$ & $-1-3-6-7-9$ & 7 \\
8 & $-2-3-4-5-6-7-9$ & $1-2-3-4-5-7-9$ & $2-3-4-5-7-9$ & 5 \\
9 & $-5-8$ & $-1-2-3-6-8$ & 8 & 1 \\
\hline
\end{tabular}


REVISTA DE LA UNIVERSIDAD DEL ZULIA. 3a época. Año 11 N 31, 2020

DOI: http://dx.doi.org/10.46925//rdluz.31.11

We can now construct the desired structural model of the problem from the finally received matrix. The final diagram was created by removing iteration modes as well as using surface segmentation.

\section{Discussion and conclusion}

Based on the results of the interpretive structural model, cultural factors are prerequisites for all factors affecting the adoption and dissemination of International Financial Reporting Standards (IFRSs) and the cost and benefits of applying IFRSs have the greatest impact on the adoption and dissemination of these standards.

The application of IFRS, which enhances the transparency of the capital market information and the international position of the country, should be complemented by the involvement of all stakeholders in the country's accounting and auditing profession, where optimal strategies for achieving such goals can be achieved. The experience of globalization reveals that opportunities are important, and challenges are trivial and solvable.

In Iran, governments and regulating and supervising organizations have embraced globalization. The implementation of International Financial Reporting Standards (IFRSs) requires the consultation and co-operation of related agencies and entities such as the Audit Organization, Association of Certified Public Accountants, the Stock Exchange and the Tax Administration. In order to apply these standards successfully, the challenges and situation must be addressed in a realistic way. To this end, an integrated approach with the effective interaction of professional institutions should be adopted. In this regard, effective planning and action for overcoming tax issues, professional translation of standards, training and development of the needed guidelines are necessary for the application of standards.

The results of this study indicate that the executives in the accounting profession are faced with some challenges for homogenizing Iranian accounting standards with International Financial Reporting Standards (IFRS). However, despite the challenges, the goal of homogenization should not be overlooked. According to the respondents, training staff to apply IFRSs, use of official accredited experts, and use of Iranian auditing firms with sufficient experience and expertise are respectively the main challenges of applying IFRSs. 
REVISTA DE LA UNIVERSIDAD DEL ZULIA. 3a época. Año 11 N³ 31, 2020 Esmaeil Dargahi \& Arash Tahriri /// Representing a Model for Implementing International...141-159

DOI: http://dx.doi.org/10.46925//rdluz.31.11

Figure 2: Structural Model of the Factors Affecting the Adoption and Dissemination of International Financial Reporting Standards (IFRSs) in Iran

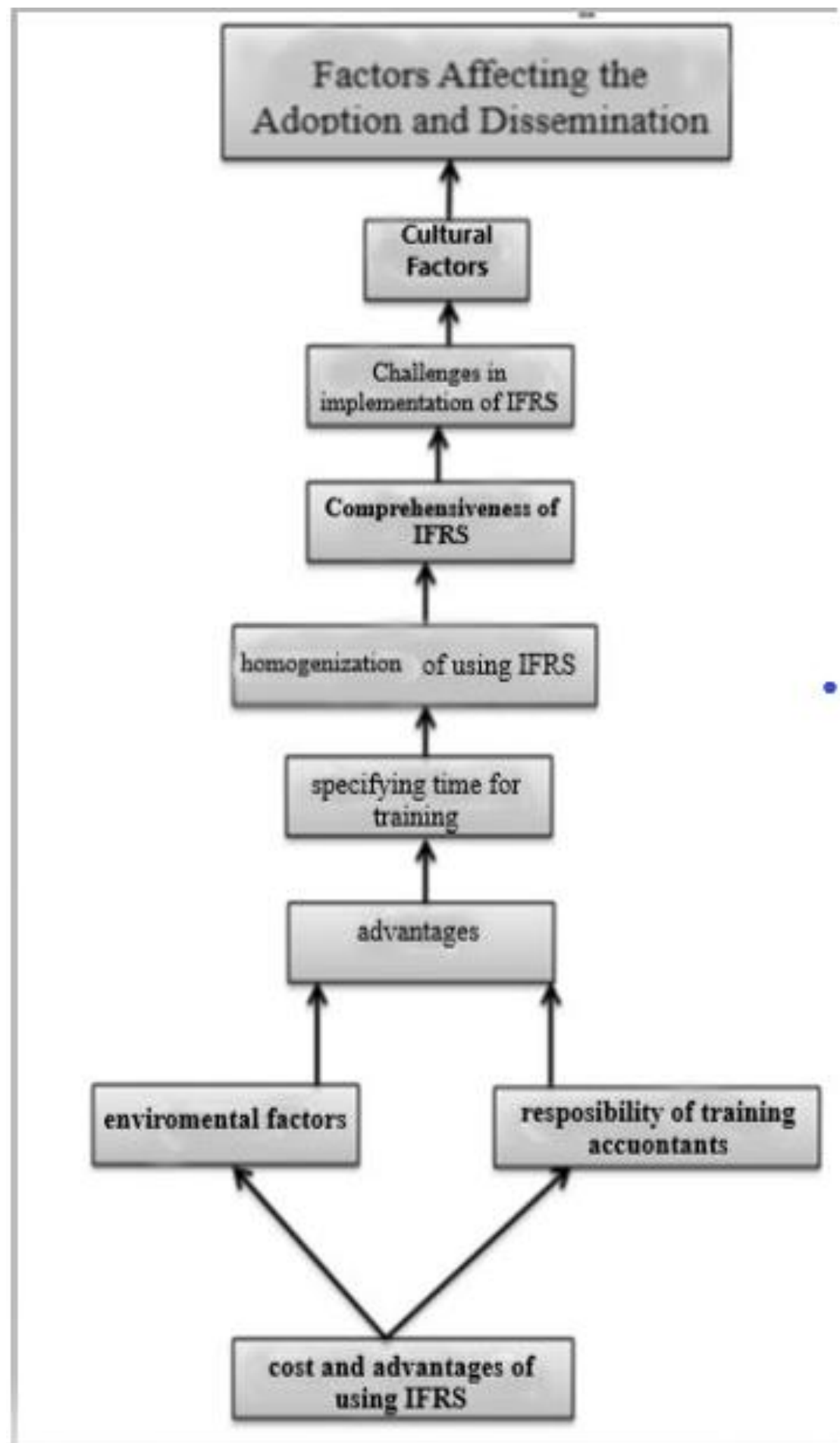


REVISTA DE LA UNIVERSIDAD DEL ZULIA. 3a época. Año 11 N³1, 2020 Esmaeil Dargahi \& Arash Tahriri /// Representing a Model for Implementing International...141-159

DOI: http://dx.doi.org/10.46925//rdluz.31.11

Considering the results of the appropriate approach to apply IFRS, voluntarily providing financial statements based on international financial reporting is preferred according to the respondents' point of view. Also, audit organization, government and supervising bodies and the accountants themselves are also responsible for training accountants in applying IFRSs. Finally, according to the respondents, IFRSs can be fully replaced by national standards.

\section{References}

Aghasi, Sahar (2015). Investigating the Barriers to the Complete Acceptance of International Financial Reporting Standards by the Tax Administration and Presenting Solutions, International Conference on Management, Economics and Financial Systems, Dubai, Parandar Andish Rahpou Company.

Ahmed, K., Chalmers, K., Khlif, H. (2013). A Meta-analysis of IFRS Adoption Effects. (2013). The International Journal of Accounting. 48, 173-217

Alzeban, A. (2016). Factors influencing adoption of the international financial reporting standards (IFRS) in accounting education, Journal of International Education in Business, Vol. 9 Iss 1. Pp. 2- 16.

Brown, P. (2011). International financial reporting standards: What are the benefits?. Accounting and Business Research, 41 (3), 269-285.

Byard, D., Li, Y., Yu, Y. (2011). The effect of mandatory IFRS adoption on financial analysts' information environment. Journal of Accounting Research, 49 (1), 69-96

Guevara Sanabria, Jaime; Tamara Contreras, Miguel; Buelvas Peralta, Rafael (2020). Convergencia a NIIF: impactos en estructura financiera de los fondos de empleados del Departamento de Sucre - Colombia, Revista de la Universidad del Zulia, 11 (29), 367-391. DOI: http://dx.doi.org/10.46925//rdluz.29.23

Hajiha, Zohreh and Hossein Rajabdari (2017). Investigating the familiarity with the concepts of International Financial Reporting Standards in accounting professors. Accounting Research, Accepted to be Published in Summer 2017.

Hejazi, Rezvan and Gholamreza Soleimani and Maryam Omidi (2013). The Effects of Adoption of International Accounting Standards on the Economic Dimension on the Environment of Iran. Journal of Accounting Advances in Shiraz University, Volume 5, Issue 1, Spring and Summer, pp. 111-187. 
REVISTA DE LA UNIVERSIDAD DEL ZULIA. 3ª época. Año $11 \mathrm{~N}^{\circ}$ 31, 2020

Hellmann, Ghanshyam Poudel Andreas \& Perera, Héctor (2014). The adoption of International Financial Reporting Standards in a non-colonized developing country: The case of Nepal. Advances in Accounting. Volume 30, Issue 1, June 2014, Pages 209-216

Lee, S., Sougiannis, T., and Wang, I. (2017). Mandatory IFRS Adoption and the Usefulness of Accounting Information in Predicting Future Earnings and Cash Flows (April 7, 2017). Available at SSRN: https://ssrn.com/abstract=2948775

Maradona, Agus Fredy \& Chand, Parmod (2018).The Pathway of Transition to International Financial Reporting Standards (IFRS) in Developing Countries: Evidence from Indonesia. Journal of International Accounting, Auditing and Taxation. Volume 30, March 2018, Pages 57 68

Nazari, Alireza, Fada'i, Iman, Tafi Mola'i, Saeed (2013). Points on the Importance of International Financial Reporting Standards and Its Advantages and Disadvantages. Journal of Economics, Nos. 1 and 2, pp. 45-52.

Nobes, C. (2010). Towards a general model of the reasons for international differences in financial reporting. Abacus, 34 (2), 162-187

Soleimani Amiri and Rasouli (2017). The Approach of Accounting Society of Iran in Adopting International Financial Reporting Standards. Empirical Accounting Research, Volume 6, Number 4, pp. 1-24.

Zahri, F., Chouabi, J. (2013). "Adoption determinants of the International Accounting Standards IAS/IFRS by the developing countries", Journal of Economics, Finance and Administrative Science, 18 (35): 56-62. 